UDC 378

\title{
SITUATIONAL EXERCISES IN THE DEVELOPMENT OF COMMUNICATION SKILLS
}

\author{
I. I. Antonenko \\ Kyiv, National Technical University of Ukraine \\ "Igor Sikorsky Kyiv Polytechnic Institute" \\ discussion17@ukr.net \\ N. V. Chizhova \\ Kyiv, National Technical University of Ukraine \\ "Igor Sikorsky Kyiv Polytechnic Institute" \\ nats7234@gmail.com
}

The article is devoted to the problem of teaching foreign languages in non-linguistic universities. The issues of ESP are considered. Particular attention is paid to develop communicative competence. The learning process should be aimed at mastering the students' communication skills - the ability to substantiate the opinion, support the conversation, discuss and solve problems in a certain professional field. Communicative situation is considered as a concrete action of communication, which includes the partners and encourages its participants to communicate. The article analyzes the creation of a professional-communicative situation, which occupies a special place in training and it is an important motive for developing and improving the skills of foreign communication. The main purpose of each situational exercise is to attract students to solve a common or professional problem. The directed activity of the student promotes the accumulation of professional experience, the formation of creativity for solving practical problems.

Key words: foreign language for professional communication; communicative approach; situational exercises; written speech; professional experience; communicative competence.

Introduction. Today, the problem of the effective using of different educational materials and the search for new ways to use them is raised. Changes in the modern Ukrainian society, which take place at all levels, lead to a reassessment of educational guidelines. The world economy requires professionals and specialists in various areas to communicate effectively in foreign languages. English is dominated in different social sectors, such as commerce, finance, higher education, the media and it is worth saying that without knowledge of a foreign language it is hardly possible to apply for a senior position and get a prestigious wellpaid job.

The effectiveness of using the communicative approach in teaching a foreign language is beyond doubt. The learning process should be aimed at mastering the students' communication skills - the ability to substantiate their own thoughts, keep up the conversation, discuss and solve problems in a particular professional field

Aims and tasks. If earlier the purpose of higher education was the formation of knowledge, skills and abilities of graduates, now, with the availability of any information, the emphasis is shifting to the formation of students' learning skills, ability and desire for self-improvement and self-education. The need for development and improvement of foreign language writing skills has been reflected in the researches of Ukrainian and foreign scholars. Thanks to the high level of development of mass media, the opportunity was opened to engage in foreign-language written communication with representatives of other cultures. Thus, the aim of the article is to analyze professional-communicative situations as important motives for developing and improving the students' skills of foreign communication, which occupy a special place in the learning environment of non-linguistic universities.

The role of communication. An important feature of the future specialist is the ability to communicate effectively, mastering of basic communication techniques in both native and foreign languages, the availability of adequate and productive communication and emotional stereotypes that directly influence the success of social and personal relationships. The particular importance in the process of communication, of course, has communicative stereotypes; when in certain situations students use formulaic sequences, patterns, clichés, phrases. There are even emotional stereotypes when persons express in a certain way their emotions, experiences, attitude to others or to a situation [1, p. 12].

Many scholas have come to the conclusion that automatic behavior is characteristic of a modern person who has a large number of contacts in many situations within one day and this behavior is the most appropriate, and sometimes the only possible one. W. James argued that almost all of our daily affairs are completely automatic and typical, even the vocabulary of each person and its forms and statements are so 
often repeated that they can indeed be considered as templates.

Due to the lack of time spent teaching a foreign language in a technical university for organizing and conducting business games, teachers widely use situational exercises. At classes, we often offer junior students situations in which they have to imagine themselves famous persons who talk about their inventions, or a hero of a book that has to solve a difficult question, or even a client of a company which realizes dreams. Sometimes such situations are unreal, but they encourage students to make a creative search, activating their interest. Sometimes the first reaction to such situations is rather restrained: students complain about their non-creativity, they need to increase the amount of time spent preparing for the task. At last, they become accustomed to such situations and take them with great enthusiasm. Students regularly perform exercises: they apologize, retell, negotiate, convince someone, communicate in a foreign language in a monologue or dialogue form.

Creating the situation takes a special place in the training. An analysis of students' work, the awareness of the importance of written communication and the creation of learning situations that can be borrowed from real life, influence on the improvement of the learning process. The task of the teacher is to create conditions and to choose such teaching methods that would help each student to show activity, creativity, expand the worldview and enrich the knowledge about country and improve linguistic knowledge. Students show cognitive activity, which is considered as the formation of the individual, which determines the intellectual response to the process or participation in the cognitive process. It includes an active life position, which means consistently defending views, initiative, activity and creativity in communication. Of course, the development of activity goes through several stages. It's important to involve a future specialist in educational and cognitive activities as they acquire knowledge. Students need the improvement of skills and abilities for learning the material, consolidating the habit of engaging in activities and the gradual development of such activities that require a strain of thought.

The situation is a combination of conditions (internal and external), such a dynamic system of interactions, which prompts the personal need for targeted activities and nourishes this activity. The situation, in the method of teaching a foreign language, is the complex of certain circumstances, typical for real life or professional events. The role of situations in learning a foreign language is difficult to overestimate because they are an effective means of motivation and stimulation. The main purpose of each situational exercise is to involve students in solving a general or professional problem [3].

Creating situations. The communicative situation is considered as a concrete action of communication, which includes communication partners, and encourages its participants to communicate [4]. It defines speech behavior, strategy and tactics of communication. Written communication is also used in various situations. Here are examples of situations that are aimed at written messages:

1. Your partner from the USA is visiting our country. He wants to communicate with representatives of the publishing house about the problems and their solutions. You want to organize a meeting for other colleagues. Write an advertisement for your colleagues.

2. Your colleagues want to organize a meeting with a famous editor. Write an invitation letter for him.

3. A famous editor from England wants to meet with your colleagues from the publishing house. Write an announcement for your colleagues.

4. You are a specialist of printing industry. You must be working at a conference tomorrow. You have to prepare the report about the development of traditional textile printing. Present the report. Answer your colleague's questions and discuss the advantages and disadvantages of the development of textile printing.

In situations where information is requested, we often write keywords about the information on the Internet, and we get an answer, since each request that is responded has already been foreseen by the employees who provide the content of the sites.

The message you received was written before the request was made, in addition you can write a comment and discuss the information. Written communication occurs when there is a lack of oral communication, and therefore it is important for those who interact, as writing a message leads to maintaining relationships. You can create different situations which are as follows:

- Situations in which students should write a message is an important motive for developing and improving the skills of foreign language writing, as it directs them to produce text for themselves.

- Situations when the learners will be participants in a seminar, conference or forum, they are discussing different questions with other participants, so they consider that it's necessary to write messages and comments.

- Situations where students make different entries or notes, record important events. These situations require not only creativity, but also the development of the ability to analyze and think critically. 
- Situations where students can write postcards or send a message, write different letters to their partners.

- Situations when students are reminded of meetings or important things that they write for themselves, colleagues or partners, so as not to forget this information.

The main purpose of each situational exercise is to involve students in solving a general or professional problem. At the publishing and printing institute with students-economists we use the textbook "Intelligent Business" (level upper-intermediate); and we develop their communication skills, offering them various situational exercises. The proposed "Setting Goals" exercise can be used to work with students of economic specialties at any stage of training.

One of the keys to managing a project successfully is to set clear goals for everyone who is involved so that they know exactly what they have to achieve and by what time. Let us consider some of the phrases that can be useful when setting goals:

a. What's the schedule for this?

b. How much are you budgeting for ...?

c. I think we should aim to ...

d. What will you need in the way of resources?

e. So what exactly would be involved?

f. When do I have to get this in by?

g. Is that feasible?

h. Does that sound reasonable?

And here are some exercises:

1. Listen to the dialogue between a project manager and members of her team. Does she respect the following advice?

When you set goals you should always make sure that they are realistic, precise and timed.

Project manager: So, Sylvia, are you ready to take on the market research side of the project?

Sylvia: Well, I really need some more detailed information. What exactly would be involved?

PM: Well, I don't have the specifics yet but I can give you a general idea. We're planning to create a new range of beauty products for women in the Asian and Arab World markets. We're convinced there's a market out there but we need to do some basic research to find out more about the products that they are already being used.

S: OK. You want us to conduct some interviews and prepare a full market report, is that so?

PM: Yeah. That's exactly it. Your report will tell us what sorts of products we need to design.

S: So, how many interviews will I have to arrange?

PM: I don't know exactly, but we can discuss that later on. And don't worry, I'm sure the Asian office will be able to help us with all that. That way you can just focus on the data.

S: OK. But what about dates? When do I have to get this in by?

PM: Let's say six weeks from now. Does that sound reasonable?

S: There's no way we can do it by then! I'd say it'll take at least two months, if not more.

What is the role of the person the project manager talks to? What goal is set? Which of phrases $(a-h)$ were used by the speakers?

2. In pairs act out some dialogues between senior manager and project leader. Set goals (time, resources and budget) together for each of the projects below.

The senior manager has asked the project leader to:

1. Take responsibility for organizing the transfer of the company's headquarters to a new location.

2. Prepare a one-week training course for senior executives.

3. Create a new company website.

4. Organize the company's annual sales conference.

The process of communication. Situational exercises prompt and encourage students to solve creative problems and develop communication skills. Performing situational exercises, the academic purpose goes to the background. Communication isn't the form of artificial learning, due to the need to perform the teacher's abstract task or the desire to get an assessment, but it occurs in the form of a natural act which meets the need for communication. In the process of communication, the formation of statements occurs under the influence of factors that are external to the language: the circumstances in which there is communication, and the relationship between objects and phenomena of reality, which are reflected in the statements. The combination of these circumstances and relations is a linguistic situation.

The development of mass communication opens new opportunities for written communication, and therefore the list of genres of written communication is increasing. In the methodology of teaching foreign languages there are different approaches to mastering the ability to create a written text. Each of these 
approaches has a number of positive aspects. In order to achieve a better effect, it is also advisable to follow a clear sequence of techniques for organizing work to develop the ability to produce texts in different situations and to further studying the development of skills to write texts of different genres. Letters to friends, business letters to colleagues, partners, notes at conferences, and information about exhibitions and outstanding events are examples of written communication.

More attention needs to be paid to the genres of written communication and similar to the genres of written texts that can be used to teach foreign-language written communication. Creating a situation is a powerful stimulation for further cognitive activity of students. They learn how to write in English in accordance with the requirements. It is important to express the opinions on professional and scientific issues in a foreign language in writing form.

With advantages of the information technology it's easier for users to get information and to search every time and anywhere the users go. The development of international mass communication requires the modern specialists of the publishing and printing industry who have the ability to search professional information. The level of English competence of a specialist is determined by the formed set of his skills in life and professional situations. It is possible to differentiate between different language structures depending on the type of language situation they represent. Thus, statements that reflect identical situations and are executed by the same linguistic means and form one language structure (model). If the lexical substitution occurs within the given situation, then the new language structure does not arise. However, the same language models can be used in a variety of situations. Therefore, all learning language material should be used in a sufficient number of new situations in order to develop active and creative mastery of them. When compiling situational exercises, the tasks should be formulated in such a way as to cause a certain students' speech response, which should be automated in the linguistic material. The description of the situation should be short and purposeful, without overloading the details with additional information. Before engaging students in a particular situation, they need to be presented some models, got acquainted with the necessary lexical constructions and explained the peculiarities of their use.

In order to improve the organizational forms and methods of classroom and independent extracurriculum work, we use such forms of educational activities for the work of students in educational and communicative situations:

- an individual form of students' work in the educational and communicative situation with the control of the teacher;

- an individual form of students' work in the educational and communicative situation with the control of the partner;

- pair form of students' work in the educational and communicative situation;

- group form of students' work in the educational and communicative situation.

Conclusions. In order to achieve a better effect, it is also advisable to follow a clear sequence of techniques for organizing work to develop the ability to produce texts for different situations and to further studying the development of linguistic skills. The learning process should be aimed at mastering the students' communication skills, the ability to substantiate the opinion, support the conversation, discuss and solve problems in a certain professional field. The systematic using of situational exercises should lead to the creation of linguistic and behavioral stereotypes and providing students with free oral or writing language skills. Situational exercises can increase students' communication and co-operation with each other. The directed activity of the student promotes the accumulation of professional experience, the formation of creativity for solving practical problems.

The next stage of our study is to develop the system of situational exercises for students-economists and conduct experimental analysis of its effectiveness.

\section{REFERENCES}

1. Берулава Г. А. Новая методология развития личности в информационном образовательном пространстве / Г. А. Берулава, М. Н. Берулава // Педагогика. - 2012. - № 4. - С. 11-20.

3. Калашникова Л. Г. Организация учебного материала и виды коммуникативных и ситуативных упражнений на продвинутом этапе обучения профессиональной коммуникации / Л. Г. Калашникова, И. А. Сергеева, Э. С. Бондаренко // Современные технологии и тактики в преподавании профессионально-ориентированного иностранного языка. - 2013. Вып. 1. - С. 136-142.

4. Каргина Е. М. Использование ситуативных упражнений при введении и активизации иноязычной лексики [Электронный ресурс] / Е. М. Каргина // Психология, социология и педагогика. - 2014. - № 11. - Режим доступа : http:psychology.snauka.ru/2014/11/3991 (дата обращения: 13.03.2017).

5. Hymes D. H. On Communicative Competence / D. Hymes. - Philadelphia : University of Pennsylvania Press, 1971. - 213 p. 


\section{REFERENCES}

1. Berulava, G. A., \& Berulava, M. N. (2012). Novaja metodologija razvitija lichnosti v informacionnom obrazovatel'nom prostranstve [New methodology of personality development in information and educational space]. Pedagogika, 4, 11-20.

3. Kalashnikova, L. G., Sergeeva, I. A., \& Bondarenko, Je. S. (2013). Organizacija uchebnogo materiala i vidy kommunikativnyh i situativnyh uprazhnenij na prodvinutom jetape obuchenija professional'noj kommunikacii [The organization of educational material and types of communicative and situational exercises at the advanced stage of training in professional communication]. Sovremennye tehnologii i taktiki v prepodavanii professional'no-orientirovannogo inostrannogo jazyka: sbornik, 1 , 136-142.

4. Karginav, E. M. (2014). Ispol'zoanie situativnyh uprazhnenij pri vvedenii i aktivizacii inojazychnoj leksiki [Using of situational exercises when introducing and activating the foreign language vocabulary]. Psihologija, sociologija i pedagogika, 11. Available at: http://psychology.snauka.ru/2014/11/3991.

5. Hymes, D. H. (1971). On Communicative Competence. Philadelphia: University of Pennsylvania Press.

I. І. Антоненко, Н. В. Чіжова. Використання ситуаційних вправ для розвитку комунікативних навичок. Стаття присвячена проблемі навчання іноземних мов студентів немовних закладів вищої освіти. Висвітлено питання, пов'язані 3 іншомовною професійною освітою сучасного фахівця. Особливу увагу приділено формуванню у студентів іншомовної компетентності. Наголошено, що навчальний процес має бути спрямований на формування у студентів комунікативних навичок - уміння обгрунтовувати власну думку, підтримувати бесіду, обговорювати та вирішувати проблеми в певній професійній сфері. Комунікативну ситуацію розглянуто як конкретну дію спілкування, в яку входять партнери по комунікації, і яка спонукає іiі учасників до спілкування. Створення професійної ситуації займає у навчанні особливе місце і $€$ важливим мотивом для розвитку й удосконалення вмінь іншомовного спілкування. Основною метою кожної ситуаційної вправи є залучення студентів до вирішення загальної або професійної проблеми. Цілеспрямована діяльність студента сприяє накопиченню професійного досвіду, формуванню креативності для вирішення практичних завдань.

Ключові слова: іноземна мова для професійних цілей; комунікативний підхід; ситуаційні вправи; писемне мовлення; професійний досвід; іншомовна компетентність. 